\title{
ARTIKELEN
}

\section{Lessen en valkuilen voor wethouders}

\author{
Henk Bouwmans
}

Dit artikel gaat over de vraag hoe het aantal valpartijen van wethouders beheerst dan wel verminderd kan worden. Achter deze hoofdvraag zitten twee deelvragen: Dient de wethouder, die inmiddels steeds professioneler zijn ambt invult, nog meer te professionaliseren? Of dient het wethouderschap een pas op de plaats te maken door te overdenken hoe het ambt op een meer politiserende wijze kan worden uitgeoefend, zodat het ook voor niet-opgeleide bestuurders toegankelijk blijft? Het antwoord op deze vragen wordt gegeven op basis van het onderzoek dat is uitgevoerd naar de valpartijen van wethouders in vier achtereenvolgende collegeperioden van 2002 tot en met 2018. Uit het onderzoek blijkt dat voor minstens de helft van de valpartijen de wethouder door eigen gedrag of nalaten direct invloed heeft op zijn valpartij. Betere voorbereiding, scherpere selectie en professionelere uitvoering en begeleiding tijdens het wethouderschap zijn wenselijk om het voor het imago, de rol en positie nadelige grote aantal valpartijen te verminderen. Tegelijkertijd maakt meer professionalisering vanwege de wens tot efficiënte en effectieve uitvoering alsook gelijktijdige decentralisering en regionalisering de wethouder steeds meer tot een manager. Dat kan het einde van het politieke wethouderschap betekenen.

Relevantie voor practitioners: dit artikel laat zien dat (a) het tussentijds vertrek en de politieke val van wethouders in de periode 2002-2018 een stabiel patroon vertonen, (b) voor minstens de helft van de valpartijen de wethouder door eigen gedrag of nalaten invloed op zijn valpartij heeft, en (c) betere voorbereiding, scherpere selectie en meer professionalisering het aantal politieke valpartijen van wethouders kunnen beperken.

\section{$1 \quad$ Inleiding}

Waarom komen wethouders ten val, wat is een mogelijke verklaring voor die valpartijen en wat kan er gedaan worden om het ten val komen van wethouders te beheersen? De centrale vraag in dit artikel is daarom: wat is er nodig om het ten val komen van wethouders te beheersen dan wel te verminderen? Bij het beantwoorden van deze vraag wordt besproken wat de betekenis van en de samenhang tussen politisering en professionalisering van het wethouderschap is. Tevens zal ik in dit artikel bespreken wat de rol van anderen kan zijn, zoals de politieke partijen, de gemeenteraad en het Ministerie van Binnenlandse Zaken en Koninkrijksrelaties. In de tweede paragraaf wordt de probleemstelling nader toegelicht. Vervolgens schets ik de opzet van het uitgevoerde onderzoek, gevolgd door de belangrijkste uitkomsten daarvan. Daarna komt de vraag aan de orde of er sprake is van meer 
politisering, waarbij wordt stilgestaan bij de relevante maatschappelijke en politieke ontwikkelingen. Vervolgens worden de soorten valpartijen geanalyseerd en wordt besproken welke lessen wethouders en anderen kunnen leren. Het artikel wordt afgerond met enkele conclusies en lessen over het wethouderschap en het antwoord op de gestelde hoofdvraag.

\section{Probleemstelling}

De positie van de wethouder staat sinds de introductie van de dualisering in 2002 onder druk. De wethouder is niet langer meer die krachtige, invloedrijke bestuurder die zijn reputatie dankt aan gerespecteerde en sprekende voorbeelden als Wibaut, Schaefer en Duivesteijn, en waardoor de lokale democratie werd gekenschetst als wethoudersland. Het waren wethouders die het verschil maakten in de ontwikkeling van stad en dorp. In elke gemeente waren er wethouders, ook van andere politieke kleuren dan van de PvdA, die het boegbeeld waren van de lokale democratie in dorp en stad. De wethouder was een belangrijke en onmisbare spil in het gemeentelijk bestuur (Elzinga, 2003).

De VVD'er Jos van Rey was in Roermond zo'n wethouder. Van Rey heeft ervoor gezorgd dat de oude binnenstad met een verlaten kazerneterrein is veranderd in een aantrekkelijk centrum waar het prettig wonen, winkelen en recreëren is. Sinds de makeover van het centrum van Roermond onder Van Reys leiding is het aangenaam toeven in de Midden-Limburgse stad aan de Maas. Tegelijkertijd is Van Rey een van de meest spraakmakende wethouders van de eerste twee decennia van deze eeuw geworden door zijn werkwijze die wordt gekleurd door vriendjespolitiek, belangenverstrengeling en cliëntelisme. Van Rey, ten val gekomen door zijn te hechte vriendschappen met lokale vastgoedondernemers, is verantwoordelijk voor de meest geruchtmakende valpartij van een wethouder na de introductie van het dualisme. Van Rey staat symbool voor de ritselende wethouder. Zoals de Amsterdamse voormalige wethouder Rob Oudkerk symbool staat voor de tippelende wethouder. Carel van Gelderen, wethouder van Wijk bij Duurstede, kleurde als wietwethouder het negatieve beeld van wethouders verder in. Het rijtje werd in 2019 voorlopig gesloten met Richard de Mos, de sjoemelende wethouder in Den Haag, ${ }^{1}$ hoewel in de eerste maanden na zijn val er ook terechte waardering was voor de wijze waarop De Mos de ombudsfunctie van de lokale bestuurder poogde nieuw leven in te blazen (Van den Dikkenberg, 2020).

Het wethouderschap is ook veranderd door de introductie van de wethouder-vanbuiten. Sinds 2002 wordt de wethouder niet meer gekozen uit de kring der raadsleden, noch is het toegestaan dat hij tevens raadslid is. Steeds vaker komt de wethouder van buiten de gemeenteraad en zelfs van buiten de gemeente. Een derde deel van de wethouders die in 2018 begonnen aan de collegeperiode is benoemd van buiten de gemeenteraad. Door de wethouder-van-buiten lijkt het beeld van

1 Bij het schrijven van dit artikel was de rechtszaak tegen de Haagse ex-wethouder nog niet gevoerd. 
het wethouderschap te veranderen: ${ }^{2}$ de wethouder-van-buiten lijkt een klus te komen doen, hij komt de gemaakte afspraken uitvoeren, uiteraard met oog voor wat politiek wenselijk is, maar, zo lijkt het, met minder hinder van alle politiek gedoe en afspraken en met minder ballast uit het verleden. Het wethouderschap is door de wethouder-van-buiten meer een baan geworden, die dan in de ene en net zo goed ook in de andere gemeente kan worden gedaan. Het roept een beeld op van een hoppende wethouder, waarbij direct een kanttekening moet worden geplaatst: het is een minderheid die als wethouder-van-buiten van de ene naar de andere gemeente gaat. Tegelijkertijd heeft de wethouder-van-buiten het wethouderschap een impuls gegeven tot verdere professionalisering van het wethouderschap. De wethouder-van-buiten heeft het karakter van die krachtige, lokale, in de eigen gemeenschap gewortelde politieke bestuurder veranderd.

Bovendien is de wethouder geen rots in de branding meer. Het beeld is dat de wethouder een vallende wethouder is geworden. Elke week verschijnt er wel een bericht in de media dat er weer een wethouder ten val is gekomen. Al deze gevallen wethouders hebben ook recht op wachtgeld. Deze rechtspositionele verworvenheid staat echter steeds meer maatschappelijk onder druk. Ondanks versoberingen blijft het publieke rumoer over dergelijke rechtspositionele, elementaire rechten die van belang zijn voor het goed functioneren van de lokale democratie telkens opnieuw de kop opsteken. Kortom, een weinig positieve beeldvorming over de wethouder, waardoor niemand, en zeker niet het bedrijfsleven, nog zit te wachten op een ex-wethouder. ${ }^{3}$

Is de positie van de wethouder verzwakt door het ten val komen van wethouders? We analyseren in het vervolg van dit artikel daarom de oorzaken van het ten val komen van wethouders: wat zijn de vertrekredenen en wat zijn de valfactoren, en welke lessen kunnen daaruit worden geleerd?

\section{De opzet van het onderzoek}

De basis voor dit artikel vormt mijn onderzoek naar het tussentijds vertrek van wethouders in de periode 2002-2018, waarvan de resultaten, trends en analyses zijn beschreven in het boek Valkuilen voor wethouders (Bouwmans, 2019). In het onderzoek zijn alle wijzigingen (opvolging, uitbreiding en het vervallen) van wethoudersposten van alle gemeenten in vier raads- en collegeperioden geregistreerd. ${ }^{4}$ De colleges van burgemeesters en wethouders in 502 gemeenten, zoals die zijn geformeerd na de gemeenteraadsverkiezingen van 2002, of toen al

2 Er is nog geen gepubliceerd kwantitatief onderzoek over de veranderende beeldvorming van het wethouderschap als gevolg van de groei van het aantal wethouders-van-buiten. Het hier beschreven beeld is gebaseerd op interviews met wethouders-van-buiten en persoonlijke gesprekken met wethouders-van-buiten en politieke ambtsdragers in de omgeving van de wethouder.

3 Rapportage onderzoek arbeidsparticipatie voormalig wethouders, E:M+MA., 25 april 2020.

4 Een overzicht van alle tussentijdse wijzigingen, inclusief de redenen van vertrek, in de periode 2002-2018 is gepubliceerd op www.decollegetafel, zie www.decollegetafel.nl/wp-content/up loads/2019/12/DCT-lijst-vertrokken-en-gevallen-wethouders-2002-2018.pdf. 
bestonden, ${ }^{5}$ vormen het beginpunt van het onderzoek. ${ }^{6}$ De onderzoeksperiode eindigt met de collegevorming na de verkiezingen van 2018 met toen nog 380 gemeenten. Het onderzoek is een kwantitatief onderzoek geworden naar de veranderende samenstelling van colleges van alle gemeenten over de gehele raads- en collegeperiode gedurende vier achtereenvolgende raads- en collegeperioden.

Het tussentijds vertrek van wethouders gedurende een bestuursperiode valt in twee groepen uiteen. Enerzijds is er de groep wethouders die vertrekt om redenen in de persoonlijke sfeer, zoals overlijden of de keuze voor een andere baan in de publieke sector of daarbuiten. Anderen stoppen om gezondheids- of persoonlijke redenen. Wanneer gezondheids- of persoonlijke redenen worden aangevoerd, blijkt dat regelmatig ook een alibi te zijn voor vermeende politieke problemen. ${ }^{7}$ De tweede groep van tussentijds vertrekkende wethouders zijn de wethouders die vanwege een politieke vertrouwensbreuk ten val komen. Voor zo'n politiek conflict blijkt altijd een direct aanwijsbare aanleiding of valfactor te noemen. Tegelijkertijd moet worden vastgesteld dat bij nadere beschouwing van de valpartij vaak sprake blijkt te zijn van een mix van factoren.

Doorslaggevend of een wethouder kan of mag blijven, is, zo concludeerden Aardema e.a. (2011), of de wethouder nog langer het wethouderschap wordt gegund. Tegelijkertijd namen de onderzoekers geen genoegen met die conclusie en hebben zij geprobeerd om tot een rangschikking te komen van soorten valpartijen. Aardema e.a. (2012) kwamen tot drie niveaus van valpartijen:

1 valpartijen die te maken hadden met de persoon en de persoonlijke hoedanigheden van de wethouder, het zogeheten microniveau;

2 valpartijen die te maken hadden met de wisselwerking met de actoren om hem/haar heen, in de lokale politiek-bestuurlijke omgeving van de wethouder, het zogeheten mesoniveau;

5 Een aantal gemeenten, zoals Utrecht en Sittard-Geleen, had in maart 2002 geen raadsverkiezingen, omdat zij kort daarvoor - eind 2000 - herindelingsverkiezingen hadden vanwege een samenvoeging van gemeenten.

6 Het onderzoek is in 2004 gestart met een jaarlijkse uitvraag onder alle griffiers waarin is gevraagd naar het tussentijds vertrek van wethouders en de redenen van vertrek. De onderzoeksgegevens over de jaren 2002 en 2003 zijn door desktopresearchonderzoek achteraf uitgevoerd. Vanaf 2010 is het onderzoek uitgevoerd door wekelijks desktopresearchonderzoek van openbare digitale bronnen (websites) van (regionale) media, gemeenten, gemeenteraden en politieke partijen. Daar waar nodig en gewenst zijn verslagen van gemeenteraadsvergaderingen in de onderzoeksperiode gecontroleerd en/of is de griffier om nadere informatie en toelichting gevraagd, vooral om helderheid te krijgen over de politieke reden van het tussentijds vertrek. Tevens is er aan het einde van het jaar een controle uitgevoerd naar de samenstelling van de colleges van burgemeesters en wethouders. Vanaf de start van het onderzoek is ervoor gekozen om alle gemeenten in het onderzoek te betrekken.

7 In het onderzoek is ervoor gekozen om de aanleiding voor het tussentijds vertrek als reden van vertrek te benoemen. De opmerking dat dit soms een alibi is voor vermeende politieke problemen is gebaseerd op de gevonden onderzoeksgegevens over de context van het vertrek: daaruit blijkt dat een verklaring van vertrek om gezondheids- of persoonlijke redenen voor een deel ook een zogeheten nette exit is om te voorkomen dat de betreffende wethouder om politieke redenen tot aftreden is gedwongen. 
3 valpartijen die hun oorsprong vinden in de maatschappelijke context en het politiek-bestuurlijke systeem, het zogeheten macroniveau.

Deze indeling is in mijn onderzoek over de periode 2002-2018 toegepast om de valpartijen van wethouders te categoriseren om te komen tot een verklaring van het ten val komen van wethouders. Verkend is aanvankelijk ook om de conflicten te groeperen op breukfactoren (in het college, met de coalitie, in de raad, of persoonlijke afweging), maar dat bleek een te beperkte benadering en daarom is gekozen voor de drie door Aardema geschetste niveaus. Als doorslaggevende factor is daarbij gekozen voor de directe aanleiding van het ten val komen van de betreffende wethouder. Een indeling in de genoemde drie niveaus kan de veronderstelling wekken dat elke politieke valpartij gemakkelijk in een van de drie genoemde niveaus kan worden gegroepeerd. Het hangt vooral van de omstandigheden en de gebeurtenissen af wat van doorslaggevende betekenis is. Wanneer een deel van de coalitiepartijen een wethouder de wacht wil aanzeggen omdat deze heeft gelogen en dus informatie heeft achtergehouden (valpartij op microniveau), maar een van de coalitiepartijen trekt de stekker uit de coalitie, waarna alle wethouders ten val komen, is de valpartij toch gegroepeerd als valpartij op het mesoniveau. Wanneer eerst de betreffende wethouder op zijn persoonlijke falen ten val komt en het leidt daarna pas tot een breuk en valpartij in de coalitie, waardoor andere wethouders ten val komen, is er een groepering zowel op het microniveau voor de betreffende wethouder als op het mesoniveau voor de overige wethouders.

\section{De uitkomsten van het onderzoek}

Het tussentijds vertrek van wethouders zowel om politieke als om niet-politieke redenen is per raads- en collegeperiode gerangschikt. Het onderzoek over de vier collegeperioden vanaf de invoering van de dualisering in 2002 levert een drietal belangrijke uitkomsten op:

1 Het aantal tussentijds vertrokken wethouders is over een gehele collegeperiode nagenoeg stabiel: vier op de tien wethouders die begonnen zijn als wethouder vertrekken of beëindigen het wethouderschap voortijdig (zie tabel 1).

2 Het aantal politiek ten val gekomen wethouders is gedurende de vier onderzochte collegeperioden vrijwel constant: twee op de tien wethouders komt ten val als gevolg van een politieke vertrouwensbreuk (zie tabel 2).

3 Tijdens elke raads- en collegeperiode is er sprake van eenzelfde golfbeweging, oplopend naar het tweede volledige collegejaar als het jaar met de meeste valpartijen, om daarna weer te dalen (zie figuur 1 ).

Deze golfbeweging onderstreept het belang om meer dan voorzichtig te zijn met het extrapoleren van een hoeveelheid valpartijen van wethouders gedurende een deel van de raads- en collegeperiode. Het aantal valpartijen van een zelfstandig jaar van de raads- en collegeperiode extrapoleren voor de gehele raadsperiode zou telkens tot een heel andere uitkomst leiden over het aantal politieke valpartijen gedurende een raads- en collegeperiode. In het perspectief van de historie is het 
Tabel 1 Aandeel tussentijds vertrokken wethouders per raads- en collegeperiode

\begin{tabular}{llll}
\hline $\begin{array}{l}\text { Raads- en college- } \\
\text { periode }\end{array}$ & $\begin{array}{l}\text { Gestarte wethou- } \\
\text { ders (aantal) }\end{array}$ & $\begin{array}{l}\text { Tussentijds ver- } \\
\text { trokken wethou- } \\
\text { ders (aantal) }\end{array}$ & $\begin{array}{l}\text { Aandeel vertrokken } \\
\text { wethouders op } \\
\text { totaal aantal wet- } \\
\text { houders }\end{array}$ \\
\hline $2002-2006$ & 1691 & 719 & $42,51 \%$ \\
$2006-2010$ & 1569 & 635 & $40,47 \%$ \\
$2010-2014$ & 1507 & 628 & $41,67 \%$ \\
$2014-2018$ & 1483 & 642 & $43,29 \%$ \\
\hline
\end{tabular}

Bron: Bouwmans, 2019: 44, tabel 6

Tabel 2 Aandeel politiek gevallen wethouders op het totaal aantal gestarte wethouders

\begin{tabular}{llll}
\hline $\begin{array}{l}\text { Raads- en college- } \\
\text { periode }\end{array}$ & $\begin{array}{l}\text { Totaal aantal } \\
\text { gestarte wethou- } \\
\text { ders }\end{array}$ & $\begin{array}{l}\text { Politiek ten val } \\
\text { gekomen wethou- } \\
\text { ders (aantal) }\end{array}$ & $\begin{array}{l}\text { Aandeel politiek } \\
\text { gevallen wethou- } \\
\text { ders op totaal aan- } \\
\text { tal gestarte wet- } \\
\text { houders }\end{array}$ \\
\hline $2002-2006$ & 1691 & 391 & $23,12 \%$ \\
$2006-2010$ & 1569 & 337 & $21,47 \%$ \\
$2010-2014$ & 1507 & 321 & $21,30 \%$ \\
$2014-2018$ & 1493 & 321 & $21,50 \%$ \\
\hline
\end{tabular}

Bron: Bouwmans, 2019: 45, tabel 8

lastig de uitkomsten van het onderzoek over de periode 2002-2018 te duiden omdat er geen vergelijkbaar gelijksoortig kwantitatief onderzoek bekend is uit de periode voor 2002. Het onderzoek dat vanuit de Thorbecke-leerstoel onder leiding van Wim Derksen is uitgevoerd gedurende een deel van drie raads- en collegeperioden tussen de raadsverkiezingen van 1986 en 1998 beperkte zich tot een deel van de betreffende raads- en collegeperiode, waaronder het tweede volledige jaar van de raads- en collegeperiode, respectievelijk 1988, 1992 en $1996 .^{8}$

Derksen e.a. (1997) constateerden dat op basis van zijn (in de tijd beperktere) onderzoek sprake was van steeds meer valpartijen van wethouders. De reden daarvoor was volgens hen de politisering van het wethoudersambt. Zij hadden daarvoor de volgende verklaring:

'Ten eerste (...) een verdere versnippering van gemeenteraden. (...) Naarmate colleges uit meer partijen moeten worden samengesteld, groeit de kans op conflicten. Ten tweede heeft de opkomst van lokale partijen en D66, die veelal een vernieu-

8 Het dagblad Trouw publiceerde in januari 2001 een onderzoek waaruit bleek dat een op de acht wethouders de duizend dagen niet haalde; 246 wethouders hielden er sinds de verkiezingen van 1998 mee op. 


\section{Figuur 1 Beeld van het jaarlijkse aantal politiek ten val gekomen wethouders} gedurende vier raads- en collegeperioden

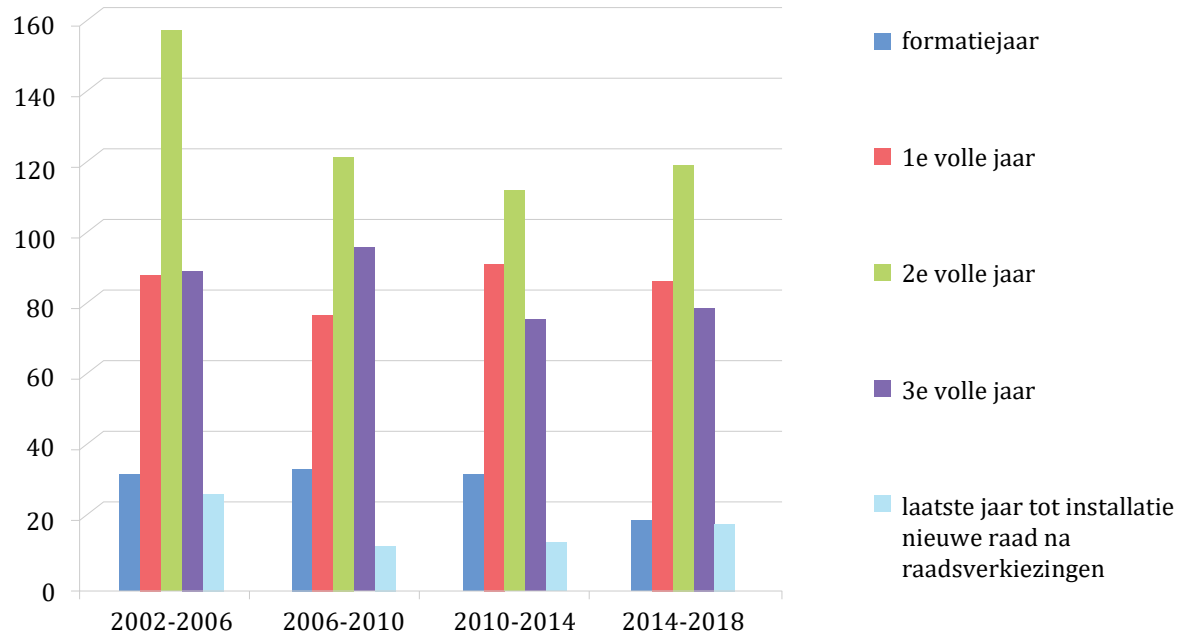

Bron: Bouwmans, 2019: 48, figuur 2

wing van het bestuur (grotere openheid, responsief bestuur) nastreven, de kans op botsingen tussen "bestuursstijlen" vergroot."

De uitkomst van het onderzoek over de periode 2002-2018 laat een andere trend zien: er is geen sprake van een groei van het aantal politieke valpartijen gedurende de vier onderzochte duale raads- en collegeperioden. Het is ook niet zo dat er steeds meer wethouders ten val komen. Integendeel, in absolute zin daalt door de afname van het aantal gemeenten het aantal vallende wethouders. In relatieve zin blijft het aantal ten val komende wethouders nagenoeg gelijk.

\section{Politiek-maatschappelijke context}

Alvorens in te gaan op de vraag welke lessen we uit de valpartijen kunnen trekken op de drie genoemde niveaus, is het belangrijk stil te staan bij de betekenis van politisering, de politiek-maatschappelijke context waarbinnen het wethouderschap is uitgeoefend en met welke ontwikkelingen de wethouder is geconfronteerd. De uitkomsten van de twee in de vorige paragraaf genoemde onderzoeken leveren een opmerkelijk verschil op. Uit het onderzoek van Derksen voor 2002 bleek dat er sprake was van telkens steeds meer vallende wethouders. Zijn verkla-

9 Derksen e.a. voerden nog een derde reden aan voor de toegenomen trend van politisering: de colleges in heringedeelde gemeenten zijn niet stabiel omdat in een aantal nieuwe gemeenten het college al ten val was gekomen. Dit argument blijft verder buiten beschouwing omdat in de periode 2002-2018 niet is waargenomen dat herindelingen sneller en vaker tot de val van fusiecolleges leidden. 
ring: politisering van het wethoudersambt. Ook anderen hebben gewezen op een (zekere) politiseringstendens (zie Aardema e.a., 2012; Korsten \& Tops, 1998). Uit het over de periode 2002-2018 uitgevoerde onderzoek blijkt dat het aantal ten val komende wethouders gelijk blijft. Is er daarmee sinds 2002 geen sprake meer van politisering in het lokaal bestuur? Om deze vraag te beantwoorden, bespreken we de politiek-maatschappelijke context waarmee wethouders in deze periode te maken hadden:

1 Het maatschappelijk klimaat is in de periode 2002-2018 in vergelijking met de periode voor 2002 fors veranderd. Onder invloed van het in 2002 vermoorde Rotterdamse raadslid Pim Fortuyn geldt het uitgangspunt: zeggen wat je denkt. Het heeft geleid tot een andere bejegening van en omgangsvormen met politici, en dus ook van en met wethouders. Deze bejegening wordt ook veroorzaakt door de horizontalisering van de samenleving; de gemeente, en daarmee de wethouder, is in de netwerksamenleving een van de vele actoren en staat niet meer aan de top van de hiërarchie. Fortuyn vormde ook de start voor een nieuwe, populistische vorm van politiek bedrijven. Deze nieuwe stroming staat voor een meer participatieve politiek en zet de bestaande politiek weg als een gesloten kartel.

2 De opkomst van social media: Facebook (vanaf 2004) en Twitter (vanaf 2006) zijn gestart als nieuwe mediafora en niet meer weg te denken in het dagelijks leven van de wethouder. De opkomst en invloed van social media zijn een gevolg van de horizontalisering en informatisering van de samenleving, maar betekenen vooral dat de communicatie met de inwoners niet meer via de regionale krant of tv verloopt, zoals in de vorige eeuw, maar rechtstreeks gebeurt. Bovendien, en dat is zo mogelijk nog belangrijker, kunnen inwoners zelf terugpraten of reageren: op Twitter kan in aanvankelijk 140 tekens, maar sinds november 2017 in 280 tekens in weinig verbloemde taal, voor iedereen zichtbaar en deelbaar, een oordeel over de wethouder worden gegeven.

3 De versplintering en de fragmentatie van het politieke landschap zijn niet alleen als een kans (Schulz \& Frissen, 2018), maar vooral ook door bestuurders als een bedreiging gekenschetst (Bouwmans, 2019: 53). Derksen noemde versplintering in de jaren tachtig en negentig een factor voor de toegenomen politisering, ten nadele van wethouders. In 2002 telde de gemeenteraad gemiddeld 5,98 fracties en dat is gestegen naar 7,50 fracties per gemeenteraad in 2018. De opkomst van lokale partijen, die andere factor die Derksen noemde, heeft zich doorgezet. Echter, we mogen niet vergeten dat in 2002 de lokale partijen qua aantal zetels al de tweede partij in gemeenteland waren. Sinds 2010 zijn de lokale partijen de grootste partij in gemeenteland. De neiging bestaat om differentiatie van het politieke landschap als een ontwikkeling van recente datum te beschouwen, maar dat lijkt op zijn minst wat kortzichtig.

Behalve ontwikkelingen zoals populistische politiek, horizontalisering van het medialandschap en verdere differentiatie van het politiek landschap, die in ieder geval op het oog kunnen bijdragen tot een meer politiserend klimaat, zijn er ook 
andere ontwikkelingen waarmee wethouders in de eerste twee decennia van de 21ste eeuw zijn geconfronteerd:

1 De schaalvergroting van het lokaal bestuur: de gemeente stond symbool voor een gemeenschap, maar door herindeling en fusies is de schaal van de gemeente steeds meer van een andere orde geworden en omvat de gemeente steeds meer diverse lokale gemeenschappen. De afstand van inwoners, dorpen en wijken tot het gemeentebestuur is daardoor vergroot. De wethouder is niet meer nabij, maar zit ver weg in het gemeentehuis. Opvallend aspect van de schaalvergroting is dat er sprake is van een kanteling: het aantal kleine gemeenten dat symbool stond voor dorpspolitiek is inmiddels fors in de minderheid, terwijl er steeds meer grote gemeenten zijn gekomen.

2 De decentralisatie van taken, zoals de Wet werk en bijstand, de Wet maatschappelijke ondersteuning en de overheveling van taken in het sociaal domein, de jeugdzorg en de participatie, heeft plaatsgevonden op basis van vaak gedetailleerde wetgeving, vergezeld van tal van voorschriften, en wordt gecontroleerd met tal van landelijke vormen van monitoring. De verantwoordelijkheid (ruimere budgetten, grotere aanspreekbaarheid op beleidsterreinen die inwoners raken) is groter geworden, maar de speelruimte voor wethouders voor eigen beleid lijkt juist door de centrale Haagse regeldrift beperkter. Politisering van deze taken is beperkt; er wordt onder leiding van de wethouder vooral naar gestreefd om deze nieuwe, gedecentraliseerde taken - zo goed en zo kwaad als het gaat - zo netjes mogelijk uit te voeren. Voor alle gedecentraliseerde taken, die vaak in regionale samenwerking worden uitgevoerd, geldt dat er in de onderzoeksperiode 2002-2018 niet of nauwelijks wethouders op ten val zijn gekomen (Bouwmans, 2019: 163-173). Dat is des te opvallender, daar gemeenteraden steen en been klagen over het gebrek aan grip en controle op vormen van regionale samenwerking.

Schaalvergroting en decentralisatie lijken een remmend effect te hebben op de mate van politisering van de lokale democratie. Schaalvergroting is gericht op het efficiënter uitvoeren van gemeentelijke taken. Decentralisatie, zeker in het sociaal domein, is gericht op uitvoering van taken in de nabijheid van inwoners tegen lagere kosten. Zeker na de decentralisatie in het sociaal domein per 1 januari 2015 hebben we gezien dat de lokale democratie vervolgens heeft gekozen voor pragmatische oplossingen: het zeker stellen van de voorzieningen. Het geringe aantal valpartijen van wethouders op deze taken is een signaal dat men op lokaal niveau vooral heel praktisch aan de slag is gegaan, vanuit de gedachte 'hoe zorgen we ervoor dat de (nieuwe) wettelijke taken zonder veel gedoe kunnen worden uitgevoerd?' (Bouwmans, 2019: 164-165).

\section{Soorten van valpartijen}

Voor het wethouderschap geldt, net zoals voor andere ambten en beroepen, dat je het meest leert van de goede voorbeelden. Tegelijkertijd valt er ook veel te leren van de fouten die wethouders hebben gemaakt. Die fouten worden het meest 
zichtbaar door de politieke valpartijen van wethouders. We bekijken de drie analyseniveaus (micro, meso en macro) van de valpartijen specifieker, om zo een beter zicht te krijgen op wat nodig is om het aantal valpartijen te beheersen of te verminderen.

\subsection{De persoonsgebonden rol van de wethouder (microniveau)}

Wethouders komen vooral ten val door redenen en aanleidingen die in het optreden van de wethouder zelf liggen (microvalfactoren, persoonlijke of persoonsgebonden rol van de wethouder). Het zijn valfactoren als gevolg van het falen of gebrekkig functioneren van de wethouder, waardoor de wethouder het vertrouwen verliest door zijn werkwijze en tekortschietende competenties. Het gaat bij deze persoonsgebonden factoren om een falende bestuursstijl, tekortschietende zelfreflectie, niet-integer gedrag en een combinatie van tekortschietende competenties en een afname van het gezag als wethouder om projecten tot een goed einde te brengen, onder meer door gebrekkige communicatie naar de inwoners en de gemeenteraad. Van de politiek ten val gekomen wethouders waren valfactoren op het microniveau voor vier op de tien van hen de reden om te moeten vertrekken. Om precies te zijn voor de gehele periode 2002-2018 ging het om $41,02 \%$ van de politiek tijdelijk of definitief ten val gekomen wethouders (Bouwmans, 2019: 50).

\subsection{De politiek-bestuurlijke omgeving van de wethouder (mesoniveau)}

Voor ruim de helft van de politiek tijdelijk of definitief ten val gekomen wethouders $(53,64 \%)$ zijn verstoorde verhoudingen in de coalitie, in het college en in de eigen fractie, het zogeheten mesoniveau, de reden voor het ten val komen (Bouwmans, 2019: 50). Wethouders spelen hierin een rol: hun optreden fungeert soms als katalysator voor het opbreken van de coalitie, maar evenzogoed zijn wethouders slachtoffer - gewild of ongewild - van de verschillende politieke opvattingen, waardoor coalitiecrises en coalitiebreuken plaatsvinden.

De oorzaken voor politiek verstoorde verhoudingen zijn niet eenduidig. Coalities, en daarmee wethouders, komen ten val als gevolg van diverse soorten conflicten. Financiële problemen vormen een belangrijke valfactor. ${ }^{10}$ Wethouders die, vooral in tijden van (dreigende) bezuinigingen, de zaak financieel niet op orde hebben, kunnen colleges in hun val meeslepen. Inhoudelijke conflicten, over zondagsrust, het plaatsen van windmolens (klimaatbeleid) en tal van andere onderwerpen, vormen ook een belangrijke oorzaak voor het ten val komen van colleges. Het is een oorzaak die hoort bij de lokale democratische politiek, want politiek gaat om het zichtbaar maken van politieke verschillen en wanneer die niet meer overbrugd kunnen worden, is de val altijd nabij. De meeste valpartijen op het mesoniveau zijn het gevolg van een cocktail van verstoorde en verzuurde persoonlijke verhoudingen tussen de lokale politieke hoofdrolspelers, in het bijzonder fractievoorzitters, partijvoorzitters, wethouders en soms ook burgemeesters: karakters

10 Meer hierover in het promotieonderzoek van Ronald Vuijk naar de rol en positie van de wethouder van financiën. Zijn onderzoek is afgerond en zijn promotie wordt in 2020 verwacht. 
die botsen, ergernis over eigenzinnig gedrag, en irritatie en boosheid over de wethouder en over wie meent de macht te hebben.

\subsection{De maatschappelijke context en het politiek-bestuurlijke systeem (macroniveau)}

Bij valpartijen op het macroniveau gaat het om valpartijen die te maken hebben met de bestuurscultuur en het dualisme. Het gaat dan om redenen voor het ten val komen van wethouders die te maken hebben met het systeem waarbinnen de wethouder werkt (het dualisme) en de politiek-bestuurlijke omgangsvormen (bestuurscultuur). In vergelijking met de micro- en mesovalfactoren is deze groep van valfactoren klein: over de periode 2002-2018 gaat het om 3,79\% van het aandeel tijdelijk of definitief om politieke redenen ten val gekomen wethouders. Wethouders die vallen op bestuurscultuur hebben te maken met een omgeving waarin de verhoudingen zijn gepolariseerd en de omgangsvormen hard zijn. Soms is er zelfs sprake van vriendjespolitiek, worden zaken in achterkamertjes besproken en afgehandeld, en spelen begrippen als collegialiteit en vertrouwen een ondergeschikte rol. ${ }^{11}$

\section{Leren van valpartijen}

Politieke valpartijen laten zien dat de lokale democratie functioneert. Hetzij door verkiezingen, hetzij tussentijds is er gelegenheid om wethouders te vervangen, op basis van de verkiezingsuitslag, dan wel omdat de wethouder(s) er niet in is (zijn) geslaagd om de meerderheid van de raad aan zijn (hun) kant te krijgen (Boogers, 2010). Bovendien hoort het bij het functioneren van de lokale democratie dat de gemeenteraad, wanneer er sprake is van een conflict of meningsverschil over het handelen, nalaten of voornemen van een of meer wethouders, de mogelijkheid heeft om de wethouder(s) al dan niet met een motie van wantrouwen of motie tot ontslag weg te sturen.

Het is mogelijk dat een wethouder niet ten val komt. Voor wethouders uit 67 gemeenten (ongeveer een zesde deel) in de periode 2002-2018 was er nooit sprake van een politieke vertrouwensbreuk. Of het uitblijven van deze valpartijen ligt aan het voortreffelijke professionele optreden van de wethouder(s) in deze gemeenten, de helder gemaakte coalitieafspraken en een eensgezinde uitvoering van de bestuurlijke werkzaamheden door de wethouder, of juist aan het vermijden van (scherpe) politisering van beleid en uitvoering, verdient nader onderzoek.

Het is daarom belangrijk wat specifieker te kijken naar de valfactoren op de drie onderscheiden niveaus en om daarbij te bezien wat de wethouder zelf kan doen.

11 Aardema e.a. (2012) noemden in deze groep ook de rol van de media, maar het is lastig om media als direct aanwijsbare veroorzaker van politieke valpartijen te benoemen. Nader onderzoek naar de rol van de media als boodschapper of veroorzaker van een politieke valpartij zou de moeite waard zijn. 
Het is van belang daarbij te beseffen dat een wethouder zowel bestuurder als politicus is. De kunst is om die rollen te verenigen, maar dat is niet altijd eenvoudig:

'Als bestuurder gaat het om consensus op basis van de feiten als basis voor besluitvorming. Het bestaansrecht van de politicus ligt bij het maatschappelijk conflict of de maatschappelijke belangentegenstelling. Is er geen conflict dan wordt dat gecreëerd, door belangenconflicten uit te vergroten. Je wilt als politicus zo veel mogelijk mensen achter je, maar de meerderheid is genoeg want bij unanimiteit word je als politicus onzichtbaar. Beeldvorming en impressie spelen hierbij een centrale rol. Het politieke bedrijf gaat om (media) aandacht en de primaire oriëntatie is op de eigen achterban. De rol van feiten is beweeglijk en manipuleerbaar.' (Ter Braak, 2018)

Balanceren tussen wat bestuurlijk wenselijk en politiek haalbaar is, lijkt daarmee de grote uitdaging voor elke wethouder. Bij het analyseren van de valpartijen is deze dubbelrol op de achtergrond altijd van betekenis, waarbij het eerder gaat om het vinden van een goede samenhang tussen professionalisering en politisering dan om een keuze tussen het een of het ander. Het lijkt verleidelijk om het grote aantal valpartijen dat te maken heeft met persoonlijke vaardigheden van de wethouder te verbinden aan zijn bestuurlijke rol. Wanneer het gaat om het inzetten van de juiste competenties, het leren van gemaakte fouten en het vermogen om nieuwe vaardigheden aan te leren, betekent dat een verdergaande professionalisering van zijn bestuurlijke rol, maar altijd ook met oog voor de politieke component van wat haalbaar is. Zo kan het grote en dominante aantal valpartijen in de politiek-bestuurlijke omgeving (verstoorde verhoudingen, breuk in coalitie, in college en met fractie) vooral worden geduid als falen op een gebrek aan gevoel voor politiek en het herkennen van veranderingen in het politieke en maatschappelijke klimaat. Maar evenzogoed spelen persoonlijke competenties en mogelijkheden om daarin verder als wethouder te professionaliseren een rol van betekenis. In de nadere analyse van hoe wethouders te werk gaan binnen de drie niveaus van valpartijen is dat te zien.

\subsection{De maatschappelijke context en het politiek-bestuurlijke systeem (macroniveau)}

Het dualisme leidde in de eerste twee perioden na de invoering ervan tot het vertrek van een zeventiental wethouders. Zij konden niet omgaan met de verandering van de bestuurlijke verhoudingen en de omgangsvormen in het duale systeem (Bouwmans, 2019: 78). Wethouders hebben geleerd hoe het dualisme werkt en beseffen dat zij hun machtsbasis niet alleen in de raad, maar ook in de wereld buiten het gemeentehuis moeten zoeken. Tegelijkertijd zijn er nog altijd wethouders die onvoldoende beseffen hoe de vertrouwensregel werkt. Zij begrijpen niet dat wanneer de raad geen vertrouwen meer in de wethouder heeft het einde oefening is. De werking van deze regel valt in een basiscursus wethouderschap uit te leggen.

De valpartijen die te maken hebben met het thema bestuurscultuur zijn lastiger te groeperen. Vaak wordt de bestuurscultuur achteraf, na het opstappen, als oorzaak 
van het vertrek aangewezen. Wethouders willen niet langer meer werken in zo'n cultuur, waar de omgangsvormen verworden zijn tot gooi- en smijtwerk en getekend worden door 'een afrekencultuur', 'een sfeer van achterdocht, wantrouwen en besluiteloosheid', 'kennelijk onvermijdelijke verharding', 'respectloos cynisme' en 'discussies [die] vaak op de persoon zijn gericht, wantrouwend zijn en te weinig inhoudelijk constructief.

De vraag is of het een falen of tekortschieten is van individuele betrokken wethouders, of slaagden zij er juist niet in om zich de heersende politiek-bestuurlijke mores (bestuurscultuur) eigen te maken? In de vele onderzoeken die zijn uitgevoerd na valpartijen op bestuurscultuur wordt vaak een oproep gedaan dat het anders moet. Het zou de moeite waard zijn om te onderzoeken welke verschillen en overeenkomsten er zijn in de omgangsvormen en de wijze van besturen en politiek bedrijven in de gemeenten waar wethouders vielen op het thema bestuurscultuur, om te kunnen bepalen of de omgeving en de politieke omgangsvormen doorslaggevend zijn dan wel het optreden van de betrokken wethou$\operatorname{der}(\mathrm{s})$. Het antwoord lijkt namelijk niet alleen te liggen in een betere voorbereiding (professionalisering) van wethouders en andere actoren in de lokale democratie, maar vermoedelijk ook in de wijze hoe politiek in deze gemeenten wordt bedreven (politisering).

\subsection{De politiek-bestuurlijke omgeving van de wethouder (mesoniveau)}

Verstoorde verhoudingen zijn in vier duale raads- en collegeperioden de belangrijkste valfactor voor wethouders. Gewild of ongewild komt een fors deel van de wethouders ten val als gevolg van verstoorde verhoudingen over allerlei soorten conflicten. Soms leidt dat direct tot een breuk in de coalitie, soms indirect. In de onderzoeksperiode 2002-2018 waren er 232 coalitiebreuken, een gemiddelde van 14,6 per jaar. In enkele gemeenten was er drie of meer keer een coalitiebreuk: Buren, Den Helder, Deventer, Edam-Volendam, Enkhuizen, Haren, Leiderdorp, Meerssen, Rotterdam en Zandvoort. De absolute uitschieter is het Limburgse Stein, waar vijf keer een coalitiebreuk in vier raadsperioden plaatsvond. De valpartijen op verstoorde verhoudingen uiten zich door conflicten en breuken in het college, tussen wethouders en coalitiepartijen, in de coalitie, en tussen wethouders en hun eigen fractie. Het is veelal een botsing tussen wat politiek wenselijk en noodzakelijk wordt geacht en wat bestuurlijk mogelijk is, waarbij de betrokken politieke actoren er niet meer in slagen om de ander nog wat te gunnen.

\section{- Inhoudelijke conflicten}

Wanneer het om inhoudelijke conflicten (bijvoorbeeld over zondagsrust of klimaatbeleid) gaat, zijn de valpartijen die daaruit voortvloeien het gevolg van de werking van de lokale democratie: inhoudelijke meningsverschillen worden gearticuleerd en de betrokken partijen slagen er niet in om deze verschillen te overbruggen. Valt dat te voorkomen of zou dat anders moeten? Ik zou zeggen van niet, want dat hoort nu eenmaal bij de werking van de democratie. Wat daarbij wel opvalt is dat de coalities in de lokale democratie, in tegenstelling tot de coalities op landelijk niveau, minder gedreven worden door het overeind houden van 
het college. Dat is ook terug te zien wanneer de valpartijen worden gerangschikt naar het soort coalitie: coalities met uitsluitend landelijke politieke partijen komen in de periode 2002-2018 minder vaak ten val dan coalities met een mix van landelijke en lokale politieke partijen.

\section{- Botsende conflicten}

Coalitiebreuken kunnen ook het gevolg zijn van persoonlijke conflicten tussen de diverse actoren (wethouders, politiek leiders in de gemeenteraad en partijen, soms ook de burgemeester) of het gevolg van het persoonlijk handelen of nalaten van een wethouder of politiek leider. Nader onderzoek is nodig om vast te stellen of de politieke stijl en omgangsvormen tussen alle betrokkenen doorslaggevend zijn, of dat het juist ontbreekt aan een evenwichtige balans tussen gewicht en voldoende tegengewicht in de politiek-bestuurlijke verhoudingen. Het is goed om dan ook te kijken of versplintering een rol van betekenis speelt. Kijkend naar de meest recente cijfers is voorzichtigheid geboden. In 2019, het eerste jaar na de start van de huidige raads- en collegeperiode, kwamen de coalitie en het college in een ongekend hoog aantal van 26 gemeenten ten val. Slechts in een minderheid (10) van deze 26 gemeenten was het aantal raadsfracties na de verkiezingen gestegen.

De veronderstelling kan ook zijn dat in deze gemeenten de problemen in de collegevorming niet goed zijn benoemd en misschien wel op de lange baan zijn geschoven. Dat zou kunnen, want het overgrote deel van de 26 gemeenten met een coalitiebreuk in 2019 had in 2018 een relatief eenvoudige en korte formatie. Meer onderzoek naar dit facet is nodig, onder meer om te kunnen bepalen of de karakters in het nieuwe college en de coalitie wel goed zijn gewogen, dan wel dat het er alleen maar om ging om een college te formeren.

Verstoorde verhoudingen en coalitiebreuken leiden vooral in kleine gemeenten vaker tot de val van wethouders. De meer persoonlijke politieke cultuur in deze kleine gemeenten heeft hier vermoedelijk mee te maken. De zogeheten dorpspolitiek waarin politieke actoren elkaar de maat nemen op wat hij of zij individueel of als partij in het verleden heeft gedaan of nagelaten, wordt als een vorm van politiek bedrijven ingezet. Zolang er geen voorschriften zijn voor het limiteren van het aantal zittingstermijnen van de wethouder, lijkt het zinvol om vooraf te toetsen of de collegeleden wel met elkaar door één deur kunnen. In grotere gemeenten, waar coalities minder vaak ten val komen op verstoorde verhoudingen, lijkt er sprake van een meer professionele ambtsopvatting van wethouders en andere politieke actoren.

Veel duidelijker lijkt het wanneer coalitiebreuken het gevolg zijn van persoonlijk handelen of nalaten van een wethouder: bijvoorbeeld gebrekkige bestuursstijl, niet-integer handelen of een gebrek aan vakbekwaamheid. Professionalisering in de zin van verbeterde vooropleiding en begeleiding met meer zelfreflectie tijdens het wethouderschap kunnen dit soort gedrag en handelen of nalaten, die aanleiding vormen voor een coalitiebreuk, helpen te voorkomen. Er moet ook worden opgemerkt dat coalitiebreuken soms worden vermeden doordat andere actoren de 
wethouder die ondermaats presteert ertoe weten over te halen om op te stappen vanwege persoonlijke redenen of gezondheidsredenen.

\section{- Samenwerkingstoets}

Meer professionalisering van individuele wethouders en colleges, vooraf en tijdens de rit, kan ertoe bijdragen dat colleges beter voorbereid en begeleid aan de start verschijnen. Er valt vooral winst te boeken in het beter voorbereiden van colleges. Dat is lastig, want het raakt het prerogatief van politieke partijen om hun kandidaat te benoemen, maar het is ook lastig om wanneer de formatie van een nieuw college klaar is nog eens de tijd te nemen voor een uitgebreide psychologische test of antropologische analyse om vast te stellen of het gekozen team van wethouders - dat ook nog moet samenwerken met de burgemeester en gemeentesecretaris - bij elkaar past. In een groot aantal gevallen is het proces van collegevorming juist begonnen in de wetenschap dat de formerende partijen weten met welke wethouder zij de collegeperiode willen gaan doen, maar ook hier lijkt het hoogst ongebruikelijk om te toetsen of te verkennen of het beoogde team wel bij elkaar past.

\subsection{De persoon van de wethouder, het zogeheten microniveau}

Falende projectverantwoordelijkheid, een gebrekkige of tekortschietende bestuursstijl en niet-integer gedrag zijn de drie belangrijkste valfactoren waardoor wethouders vanwege gebrekkige persoonlijke kwaliteiten of gedrag ten val komen. Voor al deze valfactoren geldt dat met een betere, meer professionele voorbereiding op het wethouderschap, maar ook door een betere selectie op de vakbekwame kwaliteit van kandidaten het aantal valpartijen kan afnemen. Als het om de bestuursstijl gaat, betreft het eigenwijs en/of te solistisch gedrag, gebrek aan samenwerkend vermogen, verkeerd voorbeeldgedrag, gebrek aan daadkracht, gebrek aan visie, informatie achterhouden en niet op tijd communiceren, gebrek aan resultaten, gebrek aan inlevingsvermogen en moeite met het politieke spel. Het zijn kwalificaties die aantonen dat het de wethouder ontbreekt aan leiderschap (voorbeeldgedrag), managementkwaliteiten (gebrek aan resultaten) en verbindend vermogen (eigenwijs, te solistisch, gebrek aan samenwerking). In de selectie kan daarop worden getoetst.

\section{- Projectverantwoordelijkheid}

Wanneer het gaat om falende projectverantwoordelijkheid valt op dat wethouders fouten maken die door collega's eerder ook zijn gemaakt. Wethouders komen bovengemiddeld vaker ten val op de uitvoering van een bepaald soort projecten, met name de bouw van nieuwbouwwoningprojecten (al dan niet in combinatie met de gelijktijdige ontwikkeling van zorg- en recreatiefuncties), verbouw- of nieuwbouwprojecten van cultuurpodia, schouwburgen en theaters, en de uitvoering van projecten zoals de aanleg van wegen, fietstunnels, bruggen en ovvoorzieningen.

Beslissend voor de voortzetting van het wethouderschap zijn, zo leren deze valpartijen, aspecten als: de weerstand van inwoners (buurtbewoners en gebruikers 
die onvoldoende tijdig zijn geïnformeerd), gebrekkige aansturing van het project door de wethouder en zijn ambtenaren (bijvoorbeeld door ondeugdelijke controles, eigenmachtig optreden van ambtenaren en onvoldoende procesmanagement), te ambitieuze doelstellingen of juist onhelderheid over het doel en het niet-tijdig informeren van de gemeenteraad (over oplopende financiële tekorten). Wethouders kunnen hiervan leren door in ieder geval inwoners, omwonenden en de gemeenteraad veel tijdiger en beter te informeren. Wethouders kunnen er ook van leren door de adequate aansturing van het project in samenspel met ambtenaren en soms ook collega's veel procesmatiger te organiseren, met minder risico voor tunnelvisie.

\section{- Integriteit}

Cruciaal voor het optreden van een wethouder is zijn mate van integriteit in houding en gedrag. Integriteit is veruit de meest spraakmakende valfactor voor wethouders. In de periode 2002-2018 zijn er bijna honderd getelde integriteitskwesties die vanwege het publicitaire effect schade berokkenen aan het aanzien van de wethouder en het openbaar bestuur. Wat daarbij opvalt: het zijn hoofdzakelijk mannelijke wethouders die op integriteit de fout ingaan. In deze integriteitskwesties zijn 109 wethouders ten val gekomen, onder wie slechts een handvol vrouwen. Wat ook opvalt: het beeld is dat het altijd VVD'ers zijn die een scheve schaats rijden als het gaat om integriteit. De feiten over de periode 2002-2018 zijn anders: er zijn meer wethouders van lokale partijen (36) en CDA-wethouders (23) die ten val zijn gekomen op integriteit dan VVD-wethouders (17).

Verhoudingsgewijs gaat het om een kleine groep wethouders, die op integriteitskwesties ten val komt. Social media spelen een belangrijke rol: een misstap wordt snel uitvergroot. Vanwege het publicitaire effect is elke wethouder die op integriteit ten val komt er een te veel en bederft deze het voor alle wethouders. Ook hier gaat het niet alleen om het lerend vermogen van de wethouder zelf, maar ook om dat van zijn ondersteunende ambtelijke en politieke omgeving.

Met de introductie van een integriteitstoets voor de benoeming wordt gepoogd te voorkomen dat wethouders ten val komen op integriteit. Zo'n toets vergroot de aandacht voor het thema, maar het blijft een momentopname. Bovendien ligt het risico van een beschuldiging van niet-integer gedrag of schijn van belangenverstrengeling altijd op de loer. Een wethouder die een keuze maakt in een bepaald project loopt het risico ervan te worden beticht dat hij de voorkeur geeft aan de belangen van deze of gene relatie. Iemand die ontevreden is over de gemaakte bestuurlijke keuzes of die zijn zin van de wethouder niet krijgt, heeft in het hedendaagse medialandschap voldoende mogelijkheden om dat al dan niet terecht aan te kaarten, met meer aandachttrekkend effect dan een ingezonden brief in de regionale krant in de vorige eeuw.

Wethouders kunnen zelf ook wat doen. Zij behoren politiek sensitief te zijn voor de gevoelige risico's van bevoordeling van partijgenoten, bevriende relaties en bedrijven. Te veel wethouders, niet alleen zonder ervaring, maar juist ook met veel ervaring, tonen over te weinig moreel besef te beschikken en/of geven gele- 
genheid tot onwenselijke beïnvloeding dan wel houden zich niet aan wettelijke regels en afspraken. Open kaart spelen is nog altijd niet vanzelfsprekend. Het niet op integere wijze delen van informatie kost nog steeds wethouders de politieke kop. Persoonlijk onheus of laakbaar gedrag berokkent alle wethouders nog steeds schade. Wethouders, of zij het willen of niet, zeker in het socialmediatijdperk, leven 24 uur per dag onder een glazen stolp. De lessen van oud-minister Ien Dales - 'Een beetje integer kan niet' - zijn nog altijd even actueel.

\section{De rol van anderen}

Behalve wethouders zelf kunnen ook anderen een bijdrage leveren om het aantal valpartijen van wethouders te beheersen en zelfs te verminderen. Het selectieproces van wethouders door politieke partijen kan zorgvuldiger en professioneler. In het eerste jaar van de collegeperiode, zo blijkt uit het onderzoek, komen vooral wethouders ten val die merken dat het wethouderschap niet hun ding is, of dat zij niet uit de voeten kunnen met de politieke rol die van hen wordt verwacht. Veel van deze wethouders hebben positief gereageerd op het (soms onverwachte en overhaaste) aanbod om wethouder te worden. Het is een once-in-a-lifetime chance. Vooral de kandidaten die uit een relatief veilige ambtelijke of bestuurlijke omgeving komen, hebben het vaak lastig als zij geconfronteerd worden met de schijnwerpers van $24 / 7$ publieke aandacht.

Meer aandacht voor het professioneel selecteren van kandidaat-wethouders lijkt daarom wenselijk. Om wethouder te worden zijn nog altijd geen diploma's of andere officiële bewijzen van bekwaamheid vereist (Van Ostaaijen, 2014: 71). Dat lijkt voorlopig ook niet te veranderen omdat het wethoudersambt niet wordt beschouwd als een beroep, ondanks de inspanningen van de Wethoudersvereniging met een eigen opleidingstraject. Tegelijkertijd zou het advies van de Raad voor het openbaar bestuur best kunnen worden opgevolgd, om een soort van 'knock-out criteria' in te voeren over thema's als integriteit, communicatief vermogen, samenwerkingsbereidheid en verbindend vermogen (Rob, 2016: 14). Het Ministerie van Binnenlandse Zaken en Koninkrijksrelaties, verantwoordelijk voor het aanzien en het functioneren van de lokale democratie, kan hierin een kaderstellende rol vervullen.

Wat op lokaal niveau zonder landelijke voorschriften en regelgeving kan worden geïntroduceerd, is de mogelijkheid om de voordracht van de wethouder te toetsen door een gesprek in een openbare hoorzitting van de gemeenteraad, eventueel aangevuld met vertegenwoordigers uit maatschappelijk relevante sectoren om de kennis, maar vooral 'de nieren' van de wethouder te proeven. Het confronteert wethouderskandidaten met de werkelijkheid waarmee ze vanaf hun benoeming te maken krijgen, temeer daar de screening van wethouders zich nog altijd vooral beperkt tot de door veel partijen nog steeds gehanteerde selectiewijze om 'elkaar eens goed in de ogen [te] kijken' (Brunschot e.a., 2004: 33). Overigens, wanneer er wel met sollicitatiecommissies wordt gewerkt, is de uiteindelijke beoordeling door de partijtop nog steeds doorslaggevend (Van Ostaaijen, 2014: 74). Boven- 
dien zijn de verdiensten van een kandidaat nog altijd de doorslaggevende factor (Van Ostaaijen, 2014: 71), behalve in de steeds meer voorkomende situaties dat gemeenteraden (variërend van de coalitiepartijen tot alle partijen in de raad) in een min of meer open sollicitatieprocedure op zoek gaan naar een of meer geschikte kandidaten als wethouder-van-buiten.

Uit het uitgevoerde onderzoek blijkt niet dat wethouders-van-buiten vaker of sneller ten val komen dan wethouders vanuit de gemeenteraad. Wethouders-vanbuiten hebben het wethoudersambt een meer professionele invulling gegeven. De vraag is of een meer geprofessionaliseerde wethouder ook een beter politicus is, of een betere uitvoerder van het coalitieakkoord en de toegewezen portefeuille. Een wethouder die zijn taken vervult, is een vereiste. Het uitgevoerde onderzoek over de periode 2002-2018 maakt duidelijk dat in kleine gemeenten waar is gewerkt met wethouders-van-buiten (Boekel, Grave, Harlingen, Hilvarenbeek) de dynamiek anders is geworden: minder dorpspolitiek en een professionelere uitvoering van werkzaamheden. Maar ook in grote gemeenten lijkt het er sterk op dat wethouders-van-buiten met minder ballast van de lokale politieke erfenissen hun werk zo effectief en efficiënt mogelijk voor de inwoners proberen uit te voeren.

\section{Conclusies en lessen}

De centrale vraag in dit artikel was: wat is er nodig om het ten val komen van wethouders te beheersen dan wel te verminderen, en welke rol en betekenis hebben politisering en professionalisering hierin? Duidelijk is dat de wethouder zelf daarin een rol heeft, maar dat ook andere actoren en ontwikkelingen een aandeel hebben:

1 Versplintering van het politieke landschap is op zichzelf - ondanks alle geluiden over afrekencultuur en problemen met het vinden van voldoende draagvlak - geen aanjager van meer politisering geweest in de periode 2002-2018, waardoor er meer wethouders ten val zijn gekomen. Differentiatie van het politieke landschap heeft wel tot gevolg dat de vijver waaruit politieke partijen kandidaten kunnen selecteren kleiner wordt. Het dwingt partijen tot het zoeken van kandidaten buiten de gemeente en soms zelfs buiten de eigen politieke achterban. Meer professionalisering in het selectieproces van kandidaten ligt dan voor de hand.

2 Opschaling leidt tot grotere gemeenten en dat betekent minder dorpspolitiek. Juist in kleine gemeenten zijn er verhoudingsgewijs veel valpartijen van colleges als gevolg van conflicten tussen coalitiepartijen. Met meer grotere gemeenten worden de kansen op valpartijen van colleges verkleind, ook omdat professionele uitvoering in grotere gemeenten meer centraal staat.

3 De introductie van de wethouder-van-buiten heeft de weg vrijgemaakt voor een ander type wethouder. De zogeheten hoppende wethouder houdt zich vooral bezig met het uitvoeren van de hem/haar opgedragen taken en portefeuille. De wethouder-van-buiten is een meer professionele wethouder: poli- 
tiek om het politiek bedrijven is voor deze wethouders, vooral van buiten de gemeente, van secundair belang.

4 Het proces van professionalisering van het wethouderschap wordt aangejaagd door het toegenomen aantal gedecentraliseerde en geregionaliseerde taken waarvoor vooral professionele uitvoering wenselijk is, dan wel waar de lokale democratie kiest voor een pragmatische uitvoering. Wanneer de beleidsruimte door dichtgeregelde, voorgeschreven vormen van decentralisatie van taken verder wordt beperkt en de lokale democratie - onder invloed van dualisering, decentralisering en regionalisering - juist kiest voor een pragmatische, professionele invulling lijkt verdere professionalisering van het wethouderschap onvermijdelijk.

5 De toename van het aantal wethouders-van-buiten en de pragmatische uitvoering van gedecentraliseerde taken maken van de wethouder steeds meer een bestuurlijk manager (professionalisering) en dat kan op termijn het einde betekenen van het politieke wethouderschap.

6 Het aantal valpartijen van wethouders kan beheersbaar worden gehouden, of zelfs lager worden, wanneer wethouders zich individueel en collectief professioneler laten begeleiden, bijvoorbeeld door 'coaching on the job'. Wethouders laten zich te veel leiden door de waan van de dag en er is te weinig oog voor wat elders gebeurt. Het wethouderschap is te ingewikkeld en te belastend en verdient - naast de intervisietrainingen en vakinhoudelijke cursussen van de Wethoudersvereniging - meer zelfreflectie met steun van buiten om de stad en het dorp met betekenis te blijven besturen. Bovendien zou het helpen wanneer door alle betrokken actoren bij de formatie van het college meer tijd wordt genomen om scherper te selecteren op de samenwerkingsbereidheid van het nieuwe team van collegeleden en politiek leiders.

\section{Literatuur}

Aardema, H., A.F.A. Korsten, K. Riezebos \& M.J.E.M. van Dam, De vallende wethouder. Een onderzoek naar de vertrekredenen van onvrijwillig teruggetreden wethouders in de bestuursperiode 2006-2010, Ministerie van Binnenlandse Zaken en Koninkrijksrelaties, Den Haag: 2011.

Aardema, H., M.J.G.J.A. Boogers \& A.F.A. Korsten, 'Vallende wethouders: een verkenning van de vertrekredenen van de onvrijwillig teruggetreden bestuurders op lokaal niveau', Bestuurswetenschappen, 2012/2, p. 13-33.

Boogers, M.J.G.J.A., Lokale politiek in Nederland. De logica en dynamiek van de plaatselijke politiek, Den Haag: 2010 (tweede herziene druk).

Bouwmans, H.M.J., Valkuilen voor wethouders. Lessen uit valpartijen van wethouders in de periode 2002-2018, Den Haag: 2019.

Braak, H. ter, 'Reflectie. De balanceeract van de politicus-bestuurder', De bestuurlijke rol van de raad, Nederlandse Vereniging voor Raadsleden, Den Haag: 2018, p. 25-26.

Brunschot, A.G.M. van, N. Kastelein, M.J.W. van Twist \& A.J.M. Verheij, Rekrutering en selectie van burgemeesters en wethouders. Een beknopte inventarisatie, Ministerie van Binnenlandse Zaken en Koninkrijksrelaties, Den Haag: 2004.

Derksen, W., R. Kreeft \& S. Tijsterman, 'Ten val gekomen', Binnenlands Bestuur, 1997/25, p. 26-33. 
Dikkenberg, R. van den, 'Ombudspolitiek heeft geen vieze geur', interview met Thorbeckehoogleraar Geerten Boogaard, VNG Magazine, 6 maart 2020.

Elzinga, D.J., 'Nederland moet een land van wethouders worden', Binnenlands Bestuur, 7 november 2003.

Korsten, A.F.A. \& P.W. Tops (eds.), Lokaal bestuur in Nederland, Alphen aan den Rijn: 1998.

Ostaaijen, J.J.C. van, 'Hoe word je wethouder? Een onderzoek naar de transparantie en het democratisch gehalte van de wethoudersvoordracht', Bestuurswetenschappen, 2014/2, p. 68-86.

Rob, Niet alleen een ambt, ook een ambacht. De kwaliteiten van raadsleden, burgemeesters en wethouders, Raad voor het openbaar bestuur, briefadvies, Den Haag: 2016.

Schulz, J.M. \& P.H.A. Frissen, Politieke fragmentatie. Balanceren tussen effectiviteit, legitimiteit en representativiteit, NSOB, Den Haag: 2018. 